Supporting Information

\title{
The nanoscale surface roughness influences Candida albicans biofilm formation
}

Phuc H. Le ${ }^{t,}{ }^{\uparrow}$, Duy H. K. Nguyent, Arturo Aburto-Medinat, ${ }^{t,}$, Denver P. Linklatert, Russell

J. Crawfordt, Shane MacLaughlin $¥$, and Elena P. Ivanovat ${ }^{*}$

† School of Science, College of Science, Engineering and Health, RMIT University,

Melbourne, VIC 3000, Australia

${ }^{\uparrow}$ Australian Research Council Research Hub for Australian Steel Manufacturing,

Wollongong, NSW 2500, Australia

‡BlueScope Steel Ltd, Port Kembla, NSW 2505, Australia

* Corresponding author: elena.ivanova@rmit.edu.au - Phone number: +61 99253395 
Table S1. The preparation of pTi discs.

\section{Instrument operation parameters}

\begin{tabular}{|c|c|c|c|c|c|c|}
\hline \multirow[b]{2}{*}{ Process } & \multirow[b]{2}{*}{$\begin{array}{l}\text { Magnetic discs, } \\
\text { Struers }\end{array}$} & \\
\hline & & $\begin{array}{l}\text { Speed } \\
(\mathrm{rpm})\end{array}$ & $\begin{array}{c}\text { Force } \\
(\mathrm{N})\end{array}$ & $\begin{array}{l}\text { Time } \\
\text { (min) }\end{array}$ & Directiona $^{a}$ & Solution \\
\hline \multirow{3}{*}{ Grinding } & $\begin{array}{l}\text { SiC Foil \#800 in } \\
\text { grit size }\end{array}$ & 300 & 30 & $1: 30$ & $>>$ & Water \\
\hline & & & & & & \\
\hline & $\begin{array}{l}\text { SiC Foil \#1200 } \\
\text { in grit size }\end{array}$ & 300 & 30 & $2: 00$ & $>>$ & Water \\
\hline \multirow{4}{*}{ Polishing } & Largo $(9 \mu \mathrm{m})$ & 150 & 30 & $4: 30$ & $>>$ & Dac \\
\hline & $\operatorname{Dac}(3 \mu \mathrm{m})$ & 150 & 30 & 3 & $>>$ & Largo \\
\hline & $\operatorname{Nap}(1 \mu \mathrm{m})$ & 150 & 30 & 4 & $>>$ & Nap \\
\hline & $\begin{array}{c}\text { Chem } \\
\text { OPS/ } \mathrm{H}_{2} \mathrm{O}_{2}\end{array}$ & 150 & 30 & $5: 50$ & $>>$ & $\begin{array}{l}\text { A mixture of } \\
\text { hydrogen } \\
\text { peroxide and } \\
\text { water }\end{array}$ \\
\hline
\end{tabular}


Chem EtOH $\quad$\begin{tabular}{lllll}
\hline 50 & 30 & 1 & Ethanol
\end{tabular}
a >> means the holder disc and samples were spun in the same direction.
b The proportion of the mixture of hydrogen peroxide and water was 90:10, respectively.

b The propotion of the mixture of hydrogen peroxide and water was $90: 10$, respectively.

Table S2. AFM surface roughness analysis of $\mathrm{npTi}, \mathrm{pTi}$ and glass surfaces ${ }^{\mathrm{a}}$.

\begin{tabular}{cccc}
\hline Parameter & $\mathrm{npTi}$ & $\mathrm{pTi}$ & glass \\
& & & \\
\cline { 2 - 4 } & $100 \times 100$ & $100 \times 100$ & $100 \times 100$ \\
\hline $\mathrm{S}_{\mathrm{a}}(\mathrm{nm})$ & $681.9 \pm 365.6^{*}$ & $29.7 \pm 15.9$ & $42.7 \pm 37.0$ \\
& & & \\
$\mathrm{~S}_{\mathrm{q}}(\mathrm{nm})$ & $878.9 \pm 421.9^{*}$ & $47.2 \pm 14.6$ & $53.4 \pm 40.0^{*}$ \\
& & & \\
$\mathrm{~S}_{\text {skw }}$ & $0.4 \pm 1.4^{*}$ & $19.8 \pm 23.4$ & $-0.5 \pm 0.1^{*}$
\end{tabular}




$$
\begin{aligned}
& \begin{array}{llll}
S_{\text {kur }} & 5.0 \pm 8.4^{*} & 541.3 \pm 436.6 & 2.3 \pm 2.7^{*}
\end{array} \\
& \mathrm{~S}_{\max }(\mathrm{nm}) \quad 7950.3 \pm 2477.9^{*} \quad 2301.0 \pm 782.4 \quad 622.2 \pm 196.4^{*}
\end{aligned}
$$

a The data generated through the analysis of $100 \times 100 \mu \mathrm{m}^{2}$ scan areas. The resolution of each scan was about $256 \times 256$ pixels, $n=5$.

* The asterisk indicates the statistically significant difference (in row) compared to pTi surfaces, $p<0.05$.

Table S3. Elemental composition of studied surfaces. 


\begin{tabular}{|c|c|c|c|c|c|c|c|c|c|c|}
\hline$s$ & $\mathrm{Ti}$ & 0 & $\mathrm{Na}$ & $\mathrm{Mg}$ & $\mathrm{Al}$ & $\mathrm{Si}$ & K & $\mathrm{Ca}$ & $w$ & $\mathrm{Au}$ \\
\hline $\mathrm{npTi}$ & 94.4 & 5.6 & $<\mathrm{dl}^{\mathrm{b}}$ & $<\mathrm{dl}$ & $<\mathrm{dl}$ & $<\mathrm{dl}$ & $<\mathrm{dl}$ & $<\mathrm{dl}$ & $<\mathrm{dl}$ & $<\mathrm{dl}$ \\
\hline pTi & 96.9 & 3.1 & $<\mathrm{dl}$ & $<\mathrm{dl}$ & $<\mathrm{dl}$ & $<\mathrm{dl}$ & $<\mathrm{dl}$ & $<\mathrm{dl}$ & $<\mathrm{dl}$ & $<\mathrm{dl}$ \\
\hline glass & $<\mathrm{dl}$ & 38.5 & 8.71 & 2.6 & 0.4 & 37.6 & 0.4 & 7.7 & 0.0 & 3.82 \\
\hline & & 9 & & 1 & 0 & 4 & 2 & 9 & 2 & \\
\hline
\end{tabular}

a Atomic fractions of elements detected by using energy dispersive spectroscopy (EDS).

$\mathrm{b}<\mathrm{dl}$ : below the detection limit. 

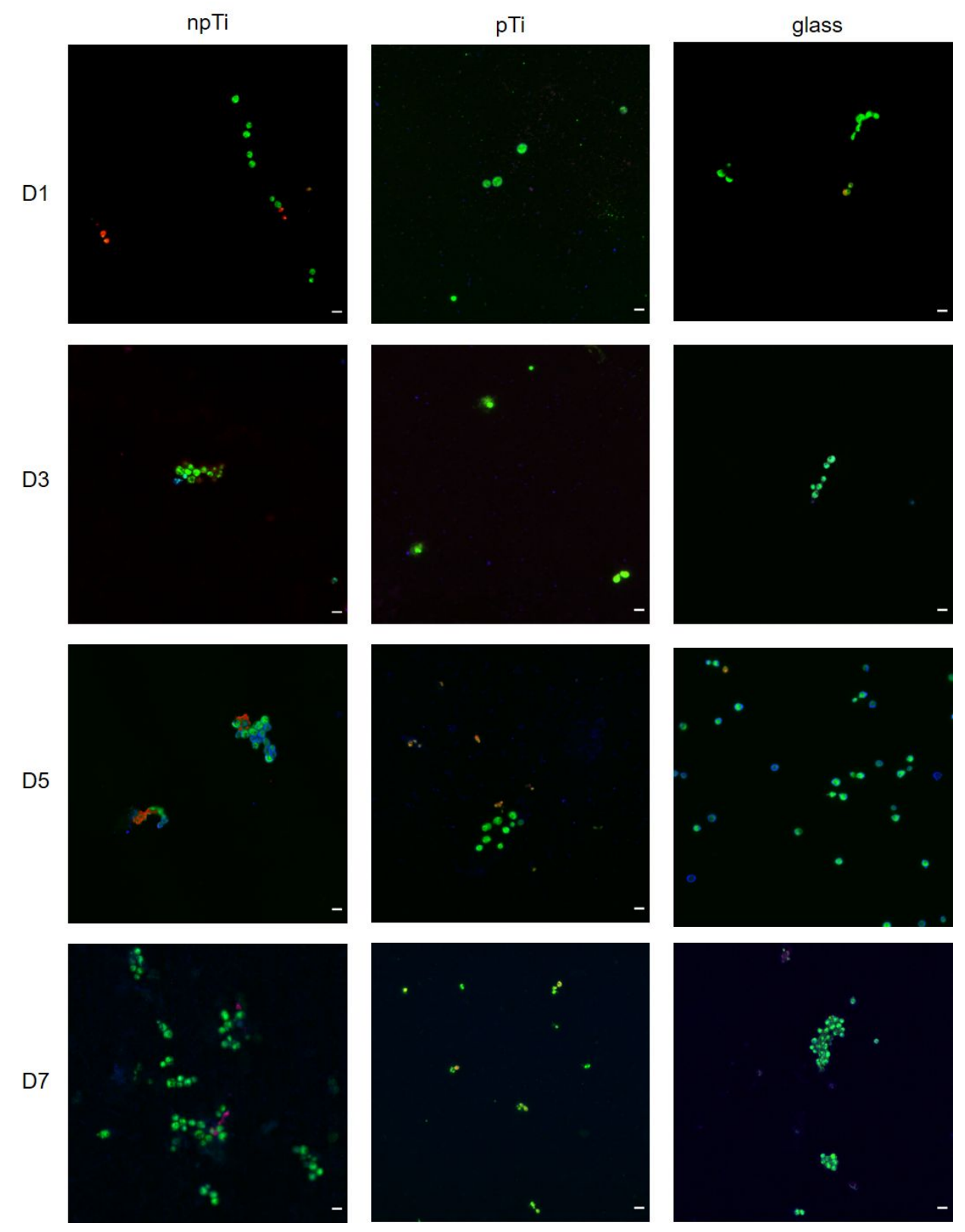

Figure S1. Attachment of $C$. albicans cells on $\mathrm{npTi}, \mathrm{pTi}$ and glass surfaces after a 7-day incubation period. Representative CLSM micrographs showing live, dead cells and cell walls (including a-mannopyranosyl and a-glucopyranosyl residues), as indicated by 
green, red and blue colours, respectively. Free amines on intracellular proteins are shown in red colour, while pink colour is resulting from overlapping of red and blue. CLSM images area: $135 \times 135 \mu \mathrm{m}^{2}$. Scale bars: $5 \mu \mathrm{m}$.
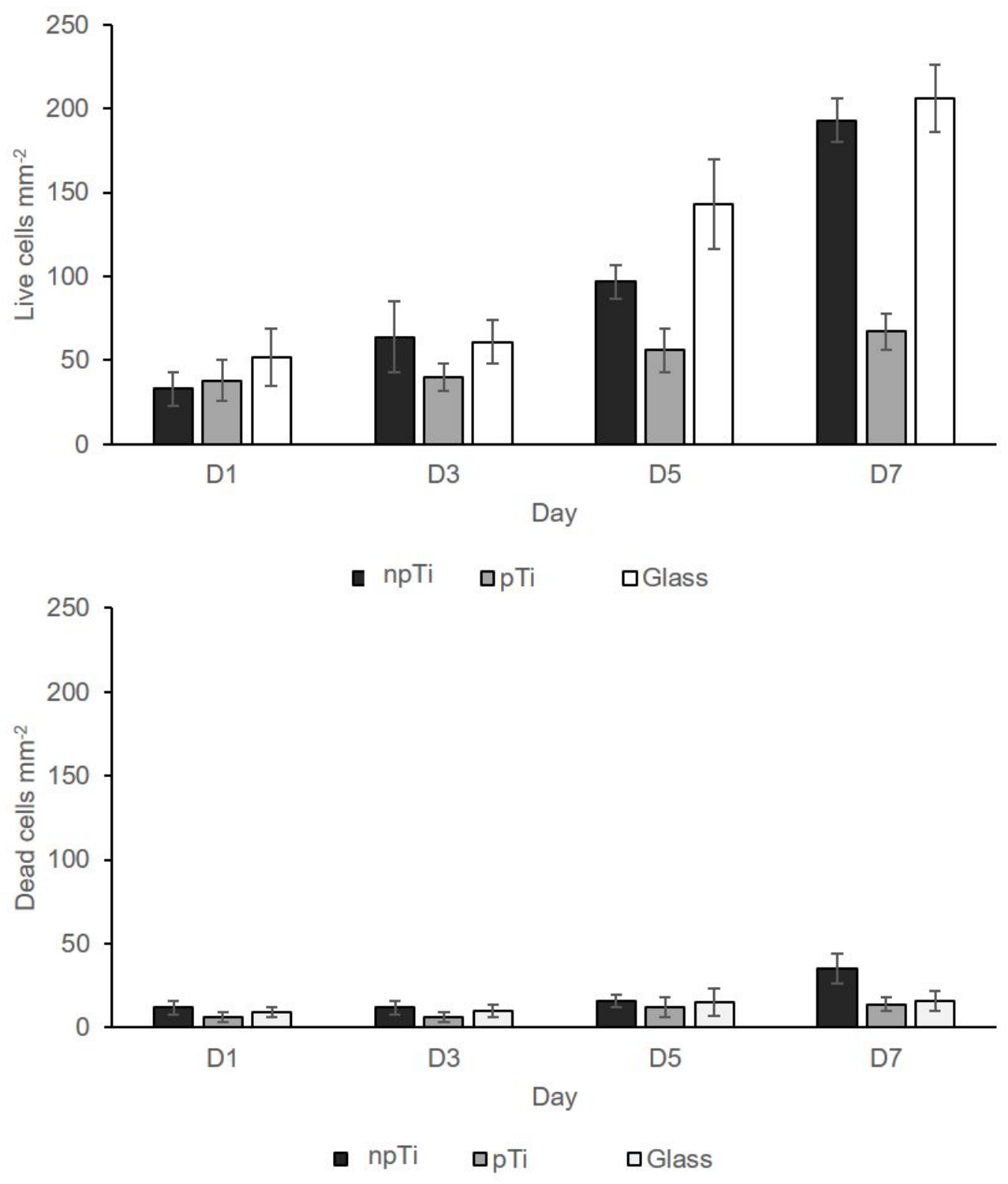
Figure S2. Assessment of the live and dead cells attached on npTi, pTi and glass after a 7-day incubation period. The number of attached cells was calculated using the CLSM images. The scanning area are $135 \times 135 \mu \mathrm{m}^{2}$. 